\title{
CLT CONSTRUCTION PERFORMANCE UNDER THERMAL LOADING
}

\author{
Katarína Dúbravská, Ludmila Tereňová, Jaroslava Štefková \\ Technical University in Zvolen \\ Slovak Republic \\ (Received August 2019)
}

\begin{abstract}
The paper deals with testing fire resistance of a vertical wooden building construction made of CLT panels subjected to the medium-scale test of the fire resistance. A model test of fire resistance with the ceramic radiation panel as the radiation heat source, with achievable temperature of radiation surface of $935^{\circ} \mathrm{C}$ at maximum was used. The aim of the experiment was to assess the experiment sample whether it meets the request of the thermal insulation and integrity under thermal loading of the model fire for $30 \mathrm{~min}$. The test resulted in the increase of temperatures on observed thermocouples and assessment of the integrity on the unexposed side of the CLT panel. The construction clearly resisted the effects of the radiation heat during $30 \mathrm{~min}$ and maintained the observed criteria of fire resistance. Charred layer of the CLT panel created on the surface of the exposed side in the thickness of $20 \mathrm{~mm}$ inhibited the heat transfer into the further layers of construction.
\end{abstract}

KEYWORDS: Cross-laminated timber (CLT), integrity, thermal insulation, medium-scale test.

\section{INTRODUCTION}

CLT panel is a building material made from several layers of spruce wood which is, according to Wieruszewski and Mazela (2017), distinctive by several positive properties. As stated by Frangi et al. (2009), dried spruce boards are placed across each other and individual layers are glued on the complete surface area. This is the way by Klippel and Frangi (2016) how large-area panels are formed. Its strength properties enable it to be used in structures not only as sheathing panels but as loadbearing construction elements as well. It is still a flammable material from the fire protection point of view. As mentioned by Östman et al. (2018), CLT panel is placed into class of reaction to fire D-s2 or Dfl-sl. Construction made of solely of a CLT panel meets the requirements on the construction element D3. In case of lining such construction by -non-flammable material (plaster board) it meets the requirements imposed on the construction element of D2 classification. 
By EN 1995-1-2 (2004) standard it is necessary to consider the fact that if the wooden surfaces are exposed to fire effects, the charring process will start. According to Kučera et al. (2012), Leško and Lopušniak (2015), the charred layer is formed on the surface under the thermal loading and thermally insulates the remaining inside layers against the effects of a fire by Wiesner and Bisby (2019). After the top layer of the CLT panel has been charred, it can fall off and then the next layer is exposed to the effects of fire and the process of charring proceeds more rapidly (Klippel et al. 2019). The studies have revealed that the falling off of the charred layer appears earlier especially when the connection of the CLT panel have been provided by a PUR adhesive. This has been mentioned by Dúbravská et al. (2019), McGregor et al. (2012), and Friquin et al. (2010). Behaviour of CLT panel in a fire depends on thickness and the number of layers which the actual building material is made from as mentioned by Klippel et al. (2014), Menis et al. (2018). By Klippel et al. (2014), CLT panels with thicker out layers achieve more positive results as in performance of the material in fire. According to Schmid et al. (2015), CLT panels can be used in a structure without sheathing (so-called unprotected) or with lining (so-called protected). Yet, a non-protected CLT panel of $80 \mathrm{~mm}$ thickness is claimed by the producer to have 60 -minute fire resistance. During 60-minute loading according to standard temperature curve, the wall shall maintain its load-bearing capacity, integrity, and thermal insulation. The review of Barber and Gerard (2015) mentions the results. Fragiacomo et al. (2013) conducted the fire tests on protected and un-protected CLT panels to state the fire resistance. They came to the following results: the time of failure of ranges between $99 \mathrm{~min}$ to $110 \mathrm{~min}$ for unprotected and protected CLT panels.

As mentioned earlier, the construction is made solely of the CLT panel and it is classified as construction element of D3 class. In case the construction element is covered by a noncombustible material, the construction element falls in to D2 class. Henek et al. (2017) state the following measures: to increase the thickness of the fire lining (fire resistant), to change the kind of lining material or to apply other form of fire protection (fire coating, spray-on, plastering).

\section{MATERIAL AND METHODS}

The main aim of the paper was to assess the fire resistance, namely the criteria of thermal insulation and the integrity of the vertical structure made of CLT panel under thermal loading.

The test sample was made of cross-glued slats without surface treatment. It is a 3-layer panel, whose individual layers were made of spruce wood with a humidity of up to $15 \%$. The panel had the following dimensions - $1000 \times 1500 \times 80 \mathrm{~mm}$, with the middle layer having a thickness of $40 \mathrm{~mm}$ and the outer layers having a thickness of $20 \mathrm{~mm}$. The gluing direction of the slats of the middle layer was vertical, the gluing direction of the slats of the outer layers was horizontal.

The test sample was loaded through the radiation panel for $30 \mathrm{~min}$. For the duration of the mid-size test, temperature behaviour was recorded by $\mathrm{NiCr}-\mathrm{Ni}$ thermocouples with a temperature range from -200 to $+1350^{\circ} \mathrm{C}$. The specific location of the individual thermocouples in the test sample was as follows (Fig. 1):

- TC1 - located on the exposed side of the sample,

- TC2 - located at the contact of the middle and outer layer at the exposed side,

- TC3 - located at the contact of the middle layer and the outer layer on the unexposed side,

- TC4 - located on the unexposed side.

The test sample was placed at a distance of $200 \mathrm{~mm}$ from the radiation panel. This distance corresponded to the radiation intensity of $43.1 \mathrm{~kW} \cdot \mathrm{m}^{-2}$, the size of the radiation surface was $480 \times 280 \mathrm{~mm}$. The radiation surface temperature was about $798^{\circ} \mathrm{C}$ for the above parameters. 
The energy source of the ceramic radiation panel was a propane-butane gas with a constant flow rate.

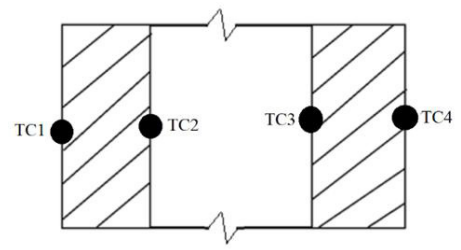

Fig. 1: Location of thermocouples on and in the sample.

\section{Assessment criteria}

In the medium-scale test, we focused on the evaluation of two fire resistance criteria thermal insulation and the integrity of the test sample. The thermal insulation criterion was evaluated on the basis of the temperature behaviour recorded during the medium-scale test. The temperature increases on the unexposed side of the sample were evaluated with respect to the initial temperature. The maximum temperature increase at any point of the unexposed side was set at $180^{\circ} \mathrm{C}$ according to EN $13501-2$ (2016). The integrity criterion was carried out during the medium-scale test by visual inspection of:

- cracks formation on the unexposed side of the test sample,

- the occurrence of a flame on the unexposed side.

The integrity and flame presence on the unexposed side were monitored during the mediumscale test (every $5 \mathrm{~min}$ ) and after the medium-scale test. If cracks and gaps were formed on the surface of the unexposed side during fire exposure to the test sample, the scale transfer through the test sample was assessed after the test had been completed. The scale transfer through the test sample was made with a $6 \mathrm{~mm}$ diameter measuring device.

\section{RESULTS AND DISCUSSION}

The behaviour of the test sample in the first seconds of the medium-scale test can be compared to the behaviour of spruce wood under fire conditions. As mentioned above (Frangi et al. 2009), the fire behaviour of the CLT panel is characterized by the behaviour of the individual layers of this material. At temperatures of $20^{\circ} \mathrm{C}$ to $150^{\circ} \mathrm{C}$, the wood starts to dry, losing water starting with free water and ending with bound water; at temperatures from $180^{\circ} \mathrm{C}$ to $250^{\circ} \mathrm{C}$ the wood is subjected to considerable chemical changes, at temperatures above $250^{\circ} \mathrm{C}$ the charring process starts accompanied by $\mathrm{CO}_{2}$ and other pyrolysis products formation (Esteves et al. 2009). Already in the first minute of the medium-scale test, there was a thermal degradation of the test sample, for which a change in colour of the wood is characteristic according to Čabalová et al. (2014), Tereňová et al. (2018). According to Kučerová et al. (2009), Zachar et al. (2017), there is a significant change in especially in the surface layers under the thermal load of wood. This process was accompanied by slight smoke generation. The flame burning occurred during $7^{\text {th }} \mathrm{min}$, whose intensity decreased from 10th min (Fig. 2). It was flameless combustion after $12^{\text {th }}$ min. As stated by Osvald and Gaff (2017), most combustible materials are characterized by burning in two phases: Phase 1 represented by the flame burning of gaseous degradation products, and phase 2 represented by flameless combustion of carbon-rich material residues. 


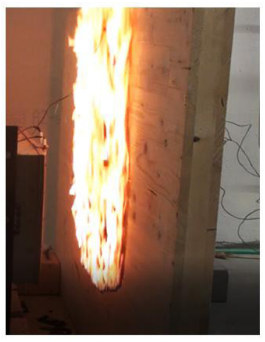

Fig. 2: Flame burning in the $7^{\text {th }}$ min.

The TC1 thermocouple was placed on the exposed side. TC1 recorded the heat emitted from the radiation panel, but also the heat that was released from the test sample during the exothermic combustion reaction. The temperature curve is shown in Fig. 3.

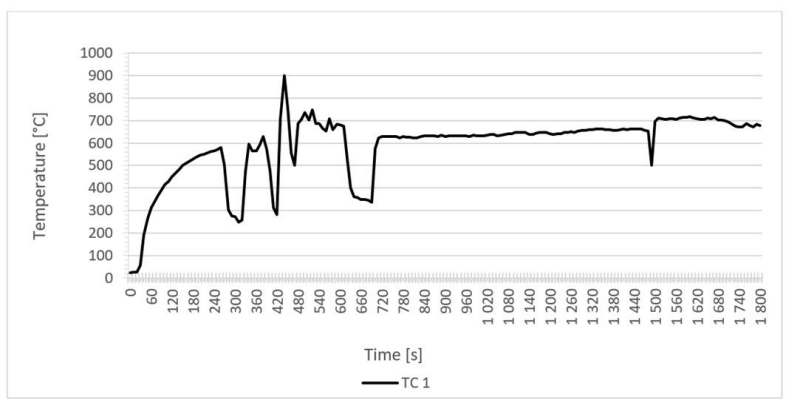

Fig. 3: Temperature development recorded on the exposed side of the test sample.

As noted, TC1 thermocouple deviations occurred at $5^{\text {th }}, 7^{\text {th }}, 11^{\text {th }}$ and $25^{\text {th }}$ min. These were caused by the failure of the TC1 thermocouple mounting and its deflection from the sample surface into the surrounding environment or towards the radiation panel surface. When the mounting failed, the TC1 thermocouple subsequently touched the surface of the radiation surface, which was characterized by temperature of $898.5^{\circ} \mathrm{C}$ (in 7 th min).

Temperature development inside the test sample was recorded via two thermocouples (Fig. 4). Thermocouple TC2 was placed $20 \mathrm{~mm}$ far from the exposed side and the thermocouple TC3 was placed $60 \mathrm{~mm}$ from the exposed side.

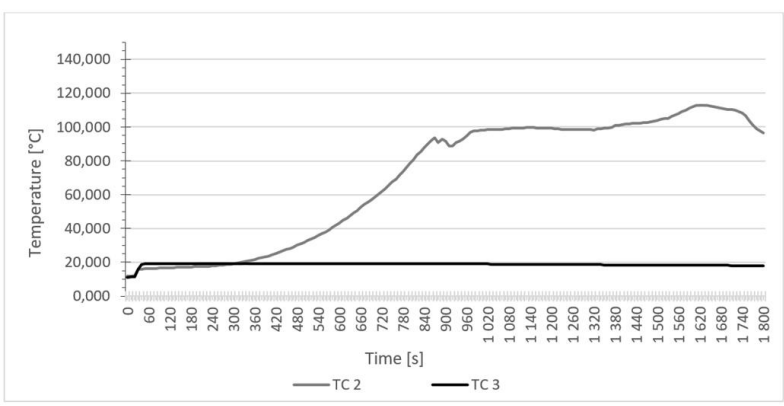

Fig. 4: Temperature development recorded inside the test sample. 
A temperature increase at the distance of $20 \mathrm{~mm}$ from the exposed side (TC2) occurred in approximately $7^{\text {th }} \mathrm{min}$. At this time, flames occurred on the surface of the test sample. This thermocouple was placed between two layers of spruce that were glued with PUR glue. It is assumed that heat released volatile products from the adhesive and thus the pressure between the layers increased. The carbonization of the layer on the exposed side and the pressure between the layers created by heating of PUR glue resulted in falling off of the charred first layer in the 30th min of the test.

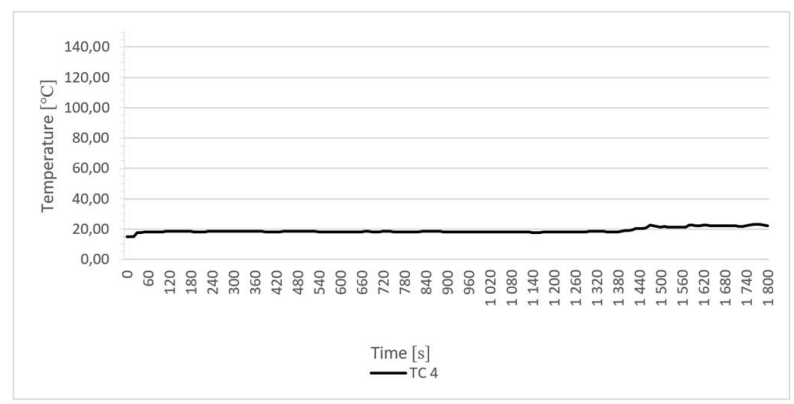

Fig. 5: Temperature development recorded on the unexposed side of the test sample.

During the entire medium-scale test, the thermocouples TC 3 and TC 4 showed no increase in temperature and their temperature ranged around $20^{\circ} \mathrm{C}$. The thermocouple $\mathrm{TC} 4$ recorded the temperature of $23^{\circ} \mathrm{C}$ in the $30^{\text {th }}$ min. Based on the temperature behaviour showed in Figs. 4 and 5 , it was concluded that the very little increase in the temperature was caused by the moderate increase of the ambient temperature.

\section{Thermal insulation criterion evaluation}

The thermal insulation criterion is assessed according to EN 13501-2 (2016) on the basis of the temperature increase at any point of the unexposed side of the sample by maximally $180^{\circ} \mathrm{C}$ considering the initial temperature measured on the unexposed side of the sample at the beginning of the test. The thermal insulation criterion on all thermocouples is evaluated in this way. The initial temperature of the individual thermocouples placed in the test sample is given in Tab. 1.

Tab. 1: Initial temperature on the individual thermocouples $\left({ }^{\circ} \mathrm{C}\right)$.

\begin{tabular}{|c|c|c|c|}
\hline \multicolumn{4}{|c|}{ Initial temperature at individual thermocouples $\left({ }^{\circ} \mathbf{C}\right)$} \\
\hline TC1 & TC2 & TC3 & TC4 \\
\hline 25.1 & 11.9 & 11.2 & 15.0 \\
\hline
\end{tabular}

Tab. 2 shows temperature increases considering the initial temperature. As can be seen in Tab. 2 and Fig. 5, there was no temperature increase of $180^{\circ} \mathrm{C}$ on the unexposed side. Maximum temperature increase on the unexposed side was $8.2^{\circ} \mathrm{C}$ during the $30^{\text {th }}$ min. Maximum temperature increase inside the test sample $\left(20 \mathrm{~mm}\right.$ from the exposed side) was $101.1^{\circ} \mathrm{C}$ in the $27^{\text {th }}$ min. Maximum temperature increase inside the test sample $(60 \mathrm{~mm}$ from the exposed side) was $8.2^{\circ} \mathrm{C}$ in the $6^{\text {th }} \min$. 
Tab. 2: Temperature increases considering the initial temperature $\left({ }^{\circ} \mathrm{C}\right)$.

\begin{tabular}{|c|c|c|c|c|}
\hline \multirow{2}{*}{ Time (min) } & \multicolumn{4}{|c|}{ Temperature increases from the initial temperature $\left({ }^{\circ} \mathbf{C}\right)$} \\
\cline { 2 - 5 } & TC1 & TC2 & TC3 & TC4 \\
\hline 1 & 286.7 & 4.3 & 7.9 & 3.1 \\
\hline 2 & 423.4 & 5.0 & 8.0 & 3.4 \\
\hline 3 & 503.8 & 5.4 & 8.2 & 3.5 \\
\hline 4 & 541.0 & 6.0 & 8.2 & 3.4 \\
\hline 5 & 248.9 & 7.3 & 8.1 & 3.4 \\
\hline 10 & 657.1 & 31.4 & 8.0 & 3.3 \\
\hline 15 & 603.9 & 79.8 & 7.9 & 3.3 \\
\hline 20 & 615.4 & 87.3 & 7.4 & 3.0 \\
\hline 25 & 672.2 & 92.0 & 7.1 & 6.3 \\
\hline 30 & 653.4 & 84.7 & 6.9 & 8.2 \\
\hline Max. increase & 728.5 & 101.1 & 8.2 & 8.2 \\
\hline
\end{tabular}

Comparing the temperature increases on TC1 and TC2 in the 30th min the difference is $568.7^{\circ} \mathrm{C}$. The distance between these two thermocouples is $20 \mathrm{~mm}$. On the surface of the test sample made from three layers of spruce wood the charred layer was formed adding its insulation capacity. Based on the above mentioned, it can be stated that the test sample m CLT panel fulfilled the thermal insulation criterion.

The integrity criterion was assessed on the basis of visual inspection. Formation of cracks or presence of flame on the unexposed side was checked in regular intervals. During the mediumscale test and after the test, no cracks were formed. The transfer of the measuring device was not applicable. The test sample made of CLT panel satisfied the integrity criterion (Fig. 6)

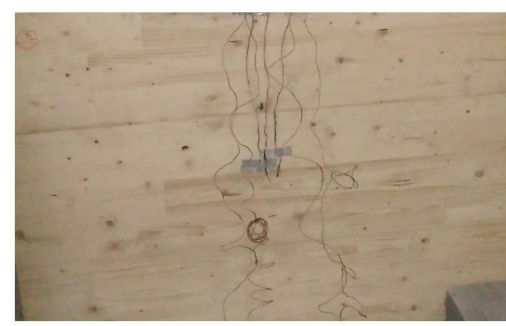

Fig. 6: Unexposed side of the test sample after the medium-scale test.

Frangi et al. (2008) also investigated the performance of CLT with no weight load in fire conditions. The test sample was $84 \mathrm{~mm}$ thick $(3 \times 28 \mathrm{~mm})$. The individual layers were glued by PUR adhesive. The authors state the charring rate as 0.6 to $0.68 \mathrm{~mm} \cdot \mathrm{min}^{-1}$ and the char layer depth as $26.5 \mathrm{~mm}$ after $39^{\text {th }} \mathrm{min}$. The fire test was finished after $39^{\text {th }} \mathrm{min}$ before the outer layer of the CLT panel was completely charred.

CLT panel performace during a fire was studied by Schmid et al. (2015). The authors carried out several tests (model test, medium-scale test, and large scale test). Various makes of test samples (protected and unprotected surfaces of a CLT panel) were tested. In the mediumscale test, the test samples were tested in a vertical furnace. The test samples with dimensions of $600 \mathrm{~mm}$ x full height $\mathrm{x} 95 \mathrm{~mm}$ were placed into the frame and mounted in the down part. The thermocouples were placed into three areas $(750 \mathrm{~mm}$ from the upper edge of the test sample, in 
the middle of the sample and in $750 \mathrm{~mm}$ from the bottom edge of the test sample). In every area three thermocouples were placed $-9.5 \mathrm{~mm}, 28.5 \mathrm{~mm}$ and $47.5 \mathrm{~mm}$ from the exposed side. During the test, also the loadbearing capacity was assessed therefore they were loaded by even weight load of $83.3 \mathrm{kN} \cdot \mathrm{m}^{-1} ; 166.7 \mathrm{kN} \cdot \mathrm{m}^{-1}$ and $250.0 \mathrm{kN} \cdot \mathrm{m}^{-1}$. Schmid et al. (2015) state that all test samples maintained integrity and insulation during the whole course of the test. The test was finished at the time when there was a load-bearing failure due to the sample deformation. The duration of the medium-scale test was, therefore, different for each sample depending on the weight load. For the test load of $83.3 \mathrm{kN} \cdot \mathrm{m}^{-1}$, the test duration time was $96 \mathrm{~min}$. For the test load of $166.7 \mathrm{kN} \cdot \mathrm{m}^{-1}$, the test duration time was $59 \mathrm{~min}$. For the test load of $250 \mathrm{kN} \cdot \mathrm{m}^{-1}$, the test duration time was $48 \mathrm{~min}$.

\section{CONCLUSIONS}

The medium-scale test was aimed at investigating the behavior of the structure made of the CLT panel under thermal loading. Despite the CLT panel classification in D-s2, d0 class according to the reaction to fire classification, a construction made of this material can achieve favourable results. When exposed to fire, a charred layer is formed on the exposed side, which generally slows down the process of thermal degradation of the rest cross-section. Based on the temperature curves monitored on the places between the individual layers of CLT panel, the conclusion that the panel clearly resisted to the radiation heat (the effects of model fire) for $30 \mathrm{~min}$ while it maintained the criterion of thermal insulation and integrity. Due to the charred layer which had a retarding effect, the degrading of the of the next layer of the CLT panel did not occur which was confirmed by the maximal temperature of $115^{\circ} \mathrm{C}$ measured by the thermocouple TC2 in the 27th min of test (Fig. 4 in 16420th second). That was also the reason why the integrity was not breached which means permanent flaming did not occur on the unexposed side and no cracks or openings which would exceed the determined limits on the unexposed side of the sample.

The described positive test results are comparable to the earlier mentioned results presented by research of foreign authors (Frangi et al. 2008). At the same time they show that the constructions of CLT panels represent a suitable and prospective material for the construction of modern multi-storey wooden buildings in the Slovak Republic.

\section{ACKNOWLEDGMENT}

This work was supported by the Slovak Research and Development Agency under contract No. APVV-17-0005 (100\%).

\section{REFERENCES}

1. Barber, D., Gerard, R., 2015: Summary of the fire protection foundation report - fire safety challenges of tall wood buildings. Fire Science Reviews 4, article number 5.

2. Čabalová, I., Kačík, F., Kačíková, D., Oravec, M., 2014: Vplyv prierezu smrekových telies na zmeny sacharidov pri termickom zatažení (The influence of cross-section of spruce wood on saccharides changes at thermal loading). Acta Facultatis Xylologiae Zvolen 56(2): 81-86. 
3. Dúbravská, K., Špilák, D., Tereňová, L', Štefková, J., 2019: Charring layer on a crosslaminated timber panel construction. Acta Facultatis Xylologiae 61(2): 109-119.

4. EN 1995-1-2, 2004: Eurocode 5: Design of timber structures. Part 1-2: General. Structural fire design.

5. EN 13501-2, 2016: Fire classification of construction products and building elements. Part 2: Classification using data from fire resistance tests, excluding ventilation services.

6. Esteves, B.M., Pereira, H.M., 2009: Wood modification by heat treatment: A review. Bioresources 4(1): 370-404.

7. Fragiacomo, M., Menis, A., Clemente, I., Bochicchio, G., Ceccotti, A., 2013: Fire resistance of cross-laminated timber panels loaded out of plane. Journal of Structural Engineering 139(12): 145: -159.

8. Frangi, A., Fontana, M., Knobloch, M., Bochicchio, G., 2008: Fire behaviour of crosslaminated solid timber panels. Fire Safety Science 9: 1279-1290.

9. Frangi, A., Fontana, M., Hugi, E., Jöbstl, R., 2009: Experimental analysis of crosslaminated timber panels in fire. Fire Safety Journal 44(8): 1078-1087.

10. Friquin, K.L., Grimsbu, M., Hovde, P.J., 2010. Charring rates for cross-laminated timber panels exposed to standard and parametric fires. World conference on timber engineering 11(1): 3293-3301.

11. Henek, V., Venkrbec, V., Novotný, M., 2017: Fire resistance of large-scale cross-laminated timber panels. IOP Conference Series: Earth and Environmental Science 95(6): 062004.

12. Klippel, M., Leyder, C., Frangi, A., Fontana, M., 2014: Fire tests on loaded crosslaminated timber wall and floor elements. Fire Safety Science 11: 626-639.

13. Klippel, M., Frangi, A., 2016: Brandverhalten von Brettsperrholz. Bautechnik 93(8): 567573.

14. Klippel, M., Schmid, J., Fahrni, R., Kleinhenz, M., Frangi, A. 2019: Vorschlag einer Standardprüfmethode für Brattsperrholz im Brandfall. Bautechnik 96(11): 824-831.

15. Kučera, P., Lokaj, A., Kačíková, D., 2012: Overenie spolahlivosti prvkov drevenej konštrukcie vystavenej vel'korozmerovej požiarnej skúške (Assessment of reliability of timber structures elements exposed to the large scale fire test). Acta Facultatis Xylologiae Zvolen 54(1): 95-104.

16. Kučerová, V., Kačík, F., Solár, R., Sivák, J., 2009: Porovnanie rôznych metód stanovenia celulózy po termickej degradácii smrekového dreva (Comparison of various methods of cellulose determination after thermal loading of spruce wood). Acta Facultatis Xylologiae Zvolen 51(1): 5-10.

17. Leško, R., Lopušniak, M., 2015: Požiarna odolnost' drevených prvkov a konštrukcií viacpodlažnej budovy stanovené podla Eurokodu 5 (Fire resistance of timber elements and structures in multi-storey building determined by Eurocode 5). Acta Facultatis Xylologiae Zvolen 57(2): 135-144.

18. McGregor, C., Hadjisophocleous, G., Benichou, N., 2013: Contribution of cross laminated timber panels to room fires. NEWBuildS, Fredericton, Canada, $186 \mathrm{pp}$.

19. Menis, A., Fragiacomo, M., Clemente, I., 2017: Fire resistance of unprotected crosslaminated timber floor panels: Parametric study and simplified design. Fire Safety Journal 30: $1-10$.

20. Östman, B., Schmid, J., Klippel, M., Just, A., Wether, N., Brandon, D., 2018: Fire design of CLT in Europe. Wood and Fiber Science 50: 68-82.

21. Osvald, A., Gaff, M., 2017: Effect of thermal modification on plameless combustion of spruce wood. Wood Research 62(4): 565-574. 
22. Schmid, J., Menis, A., Fragiacomo, M., Clemente, I., Bochicchio, G., 2015: Behaviour of loaded cross-laminated timber wall elements in fire conditions. Fire Technology 51(6): 1341-1370.

23. Tereňová, L., Dúbravská, K., Majlingová, A., 2018. The impact of the geometric shape of the log wall construction elements on their fire behaviour. Wood Research 63(4): 547-558.

24. Wieruszewski, M., Mazela, B., 2017: Cross laminated timber (CLT) as an alternative form of construction wood. Drvna Industrija 68(4): 359-367.

25. Wiesner, F., Bisby, L., 2019: The structural capacity of laminated timber compression elements in fire: A meta-analysis. Fire Safety Journal 107: 114-125.

26. Zachar, M., Majlingová, A., Mitterová, I., Cabalová, I., 2017: Influence of age and damage of the oak wood on its fire risk. Wood Research 62(3): 495-504.

Katarína Dúbravská*, L'udmila Tereñová

Technical University in Zvolen

Faculty of Wood Sciences and Technology

Department of Fire Protection

T. G. Masaryka 24

96053 Zvolen

Slovak Republic

*Corresponding author: katarina.dubravska@tuzvo.sk

Jaroslava Š́tefrová

Technical University in Zvolen

The Institute of Foreign Languages

T. G. Masaryka 24

96053 Zvolen

Slovak Republic 
